JOTE Volume 2 Nomor 1 Tahun 2020 Halaman 197-206 JOURNAL ON TEACHER EDUCATION Research \& Learning in Faculty of Education

\title{
PENERAPAN MODEL ROLE PLAYING UNTUK MENINGKATKAN MINAT BELAJAR SISWA SEKOLAH DASAR
}

\author{
Imelda Rahmi ${ }^{1}$ Dr. Nurmalina, M.Pd ${ }^{2}$ Moh. Fauziddin, M.Pd ${ }^{3}$ \\ S1 PGSD, IImu Pendidikan, Universitas Pahlawan Tuanku Tambusai \\ Bangkinang. \\ Email: Imeluptt@gmail.com
}

\begin{abstract}
Abstrak
Penelitian ini bertujuan untuk meningkatkan minat belajar siswa terhadap pembelajaran tema organ gerak hewan dan manusia dengan menerapkan model Role Playing di SDN 007 Pulau Lawas. Metode penelitian ini menggunakan penelitian tindakan kelas. Hasil penelitian menunjukkan bahwa sebelum tindakan, ketuntasan hasil minat belajar siswa hanya mencapai 35,26 \% dalam kategori sedang. Dalam melaksanakan siklus 1 Pertemuan 1 ketuntasan hasil belajar siswa mencapai $38,27 \%$ kategori sedang. Siklus 1 Pertemuan 2 ketuntasan hasil belajar siswa mencapai 45,55\% kategori sedang. Pada siklus 2 Pertemuan 1 ketuntasan hasil belajar siswa mencapai 58,92 \% kategori tinggi. Sedangkan dalam melaksanakan siklus 2 Pertemuan 2 ketuntasan hasil belajar siswa mencapai $77,36 \%$ kategori sangat tinggi. Dengan demikian dapat disimpulkan bahwa dengan penerapan model Role Playing dapat meningkatkan minat belajar siswa sekolah dasar.
\end{abstract}

Kata kunci: Minat Belajar, model Role Playing.

\begin{abstract}
This study aims to increase students' interest in learning the theme of animal and human motion organs by applying the Role Playing model at SDN 007 Pulau Lawas. This research method uses classroom action research. The results showed that before the action, the completeness of the students' interest in learning only reached $35.26 \%$ in the medium category. In carrying out cycle 1 Meeting 1 the completeness of student learning outcomes reached $38.27 \%$ moderate category. Cycle 1 Meeting 2 completeness of student learning outcomes reached $45.55 \%$ medium category. In cycle 2 Meeting 1 the completeness of student learning outcomes reached $58.92 \%$ high category. Meanwhile, in carrying out cycle 2 Meeting 2 the completeness of student learning outcomes reached $77.36 \%$ very high category. Thus it can be concluded that the application of the Role Playing model can increase the learning interest of elementary school students.
\end{abstract}

Keywords: Interest in Learning, Role Playing models. 


\section{PENDAHULUAN}

Minat belajar siswa dalam mengikuti pembelajaran merupakan sesuatu yang penting dalam kelancaran proses belajar mengajar. Siswa yang mempunyai minat belajar tinggi dalam proses pembelajaran dapat menunjang proses belajar mengajar untuk semakin baik, begitupun sebaliknya minat belajar siswa yang rendah maka kualitas pembelajaran akan menurun dan akan berpengaruh pada hasil belajar. Minat merupakan sifat yang relatif menetap pada diri seseorang. Minat adalah ketertarikan atau kecenderungan yang tetap untuk memperhatikan atau terlibat terhadap sesuatu hal karena menyadari pentingnya atau bernilainya hal tersebut. Dalam rangka mewujudkan visi dan misi pendidikan nasional yang tercantum dalam UU No. 20 Tahun 2003, diperlukan suatu pedoman dalam penyelenggaraan pendidikan atau disebut dengan kurikulum.

Undang-Undang Sisdiknas No. 20 Tahun 2003 menjelaskan bahwa kurikulum merupakan seperangkat rencana dan pengaturan mengenai tujuan, isi, dan bahan pelajaran serta cara yang digunakan sebagai pedoman penyelenggaraan kegiatan pembelajaran untuk mencapai tujuan pendidikan tertentu. Pada tahun 2013 kurikulum tingkat sekolah dasar mengalami perubahan dari kurikulum KTSP menuju kurikulum 2013. Berdasarkan wawancara awal dan observasi pada tanggal 07 Maret 2020 yang dilaksanakan di SDN 007 Pulau Lawas bersama wali kelas V SD Negeri 007 Pulau Lawas yang bernama Dartina, S.Pd. SD, data yang peneliti peroleh yakni minat belajar siswa yang masih kurang, ditunjukkan kurangnya partisipasi siswa dalam pembelajaran. Saat pembelajaran, guru menjelaskan pembelajaran dan meminta siswa untuk membaca buku pelajaran sesuai dengan materi yang diajarkan hanya sebagian siswa yang mau mendengarkan dan membaca buku pelajaran. Dengan mendengarkan penjelasan dari guru siswa diminta untuk membuat rangkuman hanya beberapa siswa yang melakukannya.

Guru memperlihatkan media pelajaran yang telah disediakan oleh sekolah tetapi siswa kurang antusias untuk melihat media tersebut yang ada didepan papan tulis, siswa memilih untuk mengobrol dan melakukan kegiatan diluar kegiatan pembelajaran. Siswa tidak memanfaatkan kesempatan yang telah diberikan oleh guru untuk bertanya terkait materi yang kurang dipahaminya. Dengan begitu guru memilih untuk memberikan pertanyaan kepada siswa untuk membangkitkan semangat siswa tetapi hanya beberapa siswa yang menjawab atau mengeluarkan pendapat. Siswa yang terlibat hanya siswa yang mendapat rangking saja. 
Menurut Djamarah (Maskurin, 2018), belajar adalah serangkaian kegiatan jiwa raga untuk memperoleh suatu perubahan tingkah laku dari pengalaman yang menyangkut kognitif, afektif dan psikomotor. Putrayasa, Syahruddin dan Margunayasa (2014) berpendapat bahwa pentingnya minat belajar itu dapat mempengaruhi keantusiasan dan keaktifan siswa dalam proses pembelajaran. Siswa yang memiliki minat belajar yang tinggi akan selalu berusaha mengikuti proses pembelajaran dengan baik. Tujuannya agar dapat memperoleh hasil belajar yang optimal. Slameto (Marleni, 2016) menyatakan siswa yang berminat dalam belajar adalah sebagai adalah siswa yang memiliki kecenderungan yang tetap untuk memperhatikan dan mengenang sesuatu yang dipelajari secara terus-menerus, memiliki rasa suka dan senang terhadap sesuatu yang diminatinya, memperoleh sesuatu kebanggaan dan kepuasan pada suatu yang diminati, lebih menyukai hal yang lebih menjadi minatnya daripada hal yang lainnya, dimanifestasikan melalui partisipasi pada aktivitas dan kegiatan.

Menurut Saefudin (Pratiwi. DKK, 2018) mengemukakan bahwa Role Playing atau bermain peran artinya mendramatiskan cara bertingkah laku dalam hubungan sosial dengan peserta didik diikutsertakan dalam memainkan peran dalam proses pembelajaran. Bermain peran adalah cara pembelajaran yang membimbing peserta didik untuk melakukan kegiatan memainkan peranan tertentu seperti yang terdapat dalam kehidupan masyarakat. Bermain peran (Role Playing) merupakan model pembelajaran yang melibatkan peserta didik untuk secara aktif dalam proses pembelajaran dengan memerankan suatu drama yang ada dalam kehidupan masyarakat dan berkaitan dengan materi yang dipelajari. Minat akan selalu terkait dengan persoalan kebutuhan dan keinginan.

Hansen (Fauziah, 2017) menyatakan bahwa Minat belajar siswa erat hubungannya dengan kepribadian, motivasi, ekspresi dan konsep diri atau identifikasi, faktor keturunan dan pengaruh eksternal atau lingkungan. Menurut Susanto (Adawiyah \& Fahri, 2017) minat merupakan apa yang disebutnya sebagai "subject-related affect." Di dalam minat dan sikap terhadap materi pelajaran. Bahwa minat itu perasaan yang menyatakan bahwa satu aktivitas, pekerjaan atau obyek itu berharga atau berarti bagi individu.

Sedangkan menurut Sabri (Syardiansah, 2016) minat belajar adalah kecenderungan untuk selalu memperhatikan dan mengingat segala sesuatu secara terus menerus yang mana dapat memperbaiki keaktifan siswa sehingga dapat mempengaruhi hasil belajar menjadi baik. Berdasarkan pendapat tersebut, 
dapat disimpulkan bahwa minat belajar ini merupakan ketertarikan anak di dalam proses pembelajaran yang mana akan menimbulkan keaktifan baik dalam mengajukan pertanyaan dan menjawab pertanyaan saat proses pembelajaran berlangsung dan anak cendrung berfikir karena minat belajar anak tersebut baik.

Menurut Ningsih (Nurhasanah \& Sobandi, 2016) indikator merupakat alat pemantau yang dapat memberikan petunjuk atau keterangan. Kaitannya dengan minat belajar siswa adalah sebagai alat pemantau yang dapat memberikan petunjuk ke arah minat dalam proses pembelajaran. Ada beberapa indiktor siswa yang memiliki minat belajar yang tinggi dapat dikenali melalui proses belajar di kelas maupun di rumah sehingga proses pembelajaran akan menjadi baik.

Indikator dari minat belajar:

\section{Perasaan Senang}

Seorang siswa yang memiliki perasaan senang atau suka terhadap suatu mata pelajaran, maka siswa tersebut akan terus mempelajari ilmu yang disenanginya. Tidak ada perasaan terpaksa pada siswa untuk mempelajari pelajaran tersebut.

\section{Ketertarikan Siswa}

Berhubungan dengan rasa ketertarikan dalam mengikuti suatu proses pembelajaran yang mana minat tersebut cenderung merasa tertarik pada orang, benda, kegiatan atau bisa berupa pengalaman afektif yang dirangsang oleh kegiatan itu sendiri.

\section{Perhatian Siswa}

Perhatian merupakan konsentrasi atau aktivitas jiwa terhadap pengamatan dan pengertian, dengan mengesampingkan yang lain dari pada itu. Siswa yang memiliki minat pada hal tertentu, dengan sendirinya akan memperhatikan hal tersebut.

\section{Keterlibatan Siswa}

Ketertarikan seseorang akan suatu hal yang mengakibatkan orang tersebut senang dan tertarik untuk melakukan atau mengerjakan kegiatan dari hal tersebut.

Berdasarkan pendapat di atas, dapat disimpulkan bahwa indikator minat belajar memiliki 4 kriteria. Jika memenuhi kriteria maka proses pembelajaran akan berjalan dengan baik. Siswa yang tertarik mengikuti pembelajaran, maka siswa akan aktif dan dapat menimbulkan rasa senang dari diri siswa bahkan 
perhatian, fokus hanya ke materi yang kita ajarkan. Siswa senantiasa mengikuti proses pembelajaran serta terlibat aktif dalam proses pembelajaran.

Bermain peran (Role Playing) merupakan model pembelajaran yang melibatkan peserta didik untuk secara aktif dalam proses pembelajaran dengan memerankan suatu drama yang ada dalam kehidupan masyarakat dan berkaitan dengan materi yang dipelajari. Tujuannya agar siswa dapat memecahkan suatu masalah dalam kehidupan nyata yang diperoleh berdasarkan pengalaman memerankan tokoh tertentu dalam suatu drama. Santoso (Nurhasanah, 2020) yang mengatakan bahwa model role playing adalah suatu cara penguasaan bahan-bahan pelajaran melalui pengembangan imajinasi dan penghayatan siswa yang di dalamnya terdapat aturan, tujuan, dan unsur senang dalam melakukan proses belajar mengajar.

Berdasarkan pendapat tersebut, dapat disimpulkan bahwa model Role Playing merupakan model pembelajaran yang mana menuntut siswa secara aktif dengan melibatkan siswa ikut serta dalam memerankan suatu materi pelajaran bersama-sama. Menumbuhkan ketertarikan mengikuti pelajaran, sehingga perhatian siswa baik serta dapat memecahkan suatu masalah dalam kehidupan nyata yang diperoleh berdasarkan pengalaman memerankan tokoh tertentu dalam suatu drama.

Menurut Slameto (Rusmiati, 2017) beberapa indikator minat belajar yaitu: perasaan senang, ketertarikan, penerimaan, dan keterlibatan siswa. Jadi, dapat disimpulkan bahwa indikator minat belajar memiliki 4 kriteria. Jika memenuhi kriteria maka proses pembelajaran akan berjalan dengan baik. Siswa yang tertarik mengikuti pembelajaran, maka siswa akan aktif dan dapat menimbulkan rasa senang dari diri siswa bahkan perhatian, fokus hanya ke materi yang kita ajarkan. Siswa senantiasa mengikuti proses pembelajaran serta terlibat aktif dalam proses pembelajaran.

\section{METODE}

Metode penelitian adalah prosedur yang menggambarkan penelitian yang dilaksanakan dan merupakan sebuah kegiatan penelitian yang bertujuan untuk memperbaiki kekurangan-kekurangan yang terdapat dalam pembelajaran di kelas yaitu dengan cara melakukan tindakan-tindakan tertentu agar dapat memperbaiki serta meningkatkan kualitas pembelajaran yang diharapkan dapat tercapai. Pada penelitian ini dibutuhkan adanya partisipasi dan kolaborasi, artinya penelitian terlibat secara langsung dan adanya kalaborasi antara 
penelitian dan wali kelas $\mathrm{V}$ yang merupakan mitra dalam penelitian ini. Pada penelitian yang akan dilakukan ini menggunakan jenis Penelitian Tindakan Kelas (PTK).

Menurut Arikunto, (Saraswati, 2018) bahwa Penelitian Tindakan Kelas (PTK) merupakan suatu pencermatan terhadap kegiatan belajar berupa sebuah tindakan, yang sengaja dimunculkan dan terjadi dalam sebuah kelas secara bersama. Penelitian ini dilaksanakan pada kelas V di SDN 007 Pulau Lawas, Kecamatan Bangkinang. Alasan pemilihan lokasi karena terdapat masalah pada rendahnya minat belajar siswa kelas V. Penelitian ini dilaksanakan pada semester ganjil tahun 2020. Penelitian ini dilaksanakan dalam 2 siklus, yaitu: siklus I dan siklus II, masing-masing siklus terdiri dari 2 pertemuan. Pada masingmasing siklus terdiri dari perencanaan, pelaksanaan, pengamatan, refleksi. Tahapan pada siklus dapat digambarkan sebagai berikut:

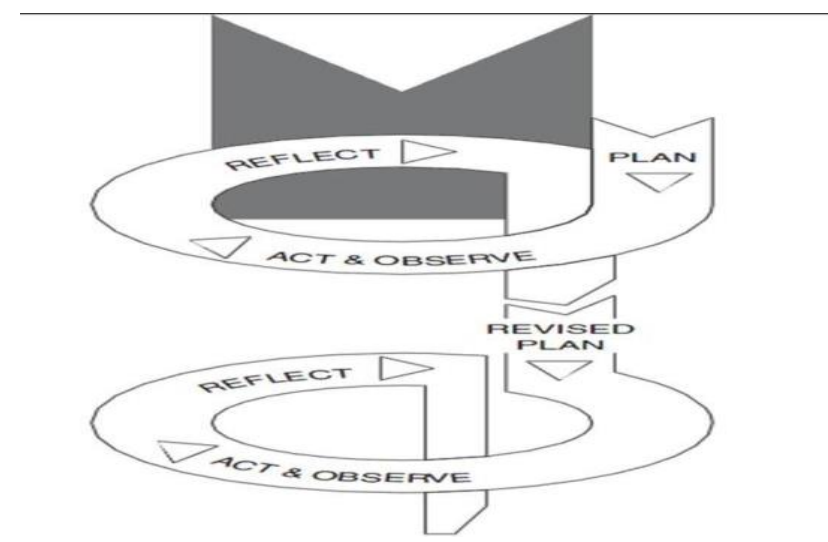

\section{Gambar 3.1}

Siklus penelitian tindakan

Kemmis, Mc. Taggart, dan Nixon (Rahmawati dan Suwarjo, 2016)

Adapun teknik pengumpulan data yang digunakan dalam penelitian ini adalah:

1. Kuesioner. Kuesioner merupakan sejumlah pertanyaan tertulis yang digunakan untuk memperoleh informasi dari responden dalam arti laporan tentang pribadinya, atau hal-hal yang ia ketahui. Kuesioner dalam penelitian ini digunakan untuk mengukur minat belajar siswa pada pembelajaran tematik dan diisi oleh siswa pada penelitian ini. Kuesioner diberikan kepada siswa sebanyak dua kali yaitu pra siklus dan setelah pelaksanaan tindakan disetiap siklus.

2. Pengamatan (Observasi). Teknik observasi yang digunakan dalam penelitian ini adalah pengamatan secara langsung. Hal-hal yang diamati antara lain: 
proses pembelajaran, cara penjelasan guru tentang materi, cara guru memberikan stimulus kepada siswa, membimbing siswa dalam kelompokkelompok dan pemahaman siswa terhadap aturan yang telah dibuat.

3. Dokumentasi. Dokumentasi yang digunakan untuk memperoleh data yang meliputi hasil tes siswa, angket minat belajar siswa, observasi minat belajar siswa dan observasi terlaksanannya model Role Playing guru, serta foto-foto kegiatan belajar siswa pada kelas V SD Negeri 007 Pulau Lawas.

\section{PEMBAHASAN}

Penelitian yang dilaksanakan di SDN 007 Pulau lawas dengan mengikuti protokol kesehatan, yang mana siswa menggunakan masker, siswa dan guru mencek suhu badan sebelum memasuki lingkungan sekolah. Siswa masuk kelas dengan mencuci tangan terlebih dahulu. Pada kondisi awal minat belajar siswa pada kelas V SDN 007 Pulau Lawas yang diperoleh peneliti dengan memberikan angket pra siklus dan pengamatan yang dilaksanakan sebelum melaksanakan penelitian yang mana menunjukkan perolehan skor minat pra siklus sebesar $35,26 \%$ yang mana kriteria pada perolehan ini dalam kriteria sedang.

Berdasarkan kondisi awal minat belajar siswa tersebut maka diberikannya sebuah tindakan yakni penerapan model role playing pada tema organ gerak hewan dan manusia dengan tujuan meningkatkan minat belajar siswa. Peneliti dengan bantuan kedua teman sejawat melaksanakan tindakan, yang mana tindakan dilaksanakan dalam dua siklus yang mana setiap siklus terdiri atas dua pertemuan.Setiap pertemuan dilaksanakan selama 2 jam pelajaran.

Melalui penerapan model role playing, guru dapat menumbuhkan dan meningkatkan minat belajar siswa dengan adanya bermain peran, dengan adanya hal ini dapat membuat siswa lebih aktif, tertarik dan terlibat aktif dalam pembelajaran. Dan juga bisa menumbuhkan perhatian dan perasaan senang dalam mengikuti proses pembelajaran. Peneliti menerapkan dalam kegiatan pembelajaran model yg inovatif. Model pembelajaran merupakan acuan yang digunakan dalam proses pembelajaran, yang mana acuan ini secara sistematis dan tersusun.

Bermain peran (Role Playing) merupakan model pembelajaran yang melibatkan peserta didik untuk secara aktif. Memerankan suatu drama yang ada dalam kehidupan masyarakat dan berkaitan dengan materi yang dipelajari. Adanya model ini maka 4 indikator dari minat belajar akan tercapai. 
Hasil minat belajar siswa dalam penelitian ini diperoleh melalui angket minat belajar siswa. Lembar observasi guru digunakan saat guru menerangkan dan lembar observasi siswa juga digunakan saat proses pembelajaran berlangsung. Observer pada penelitian ini 2 teman sejawat. Teman sejawat 1 yang mengamati proses pembelajaran siswa dan teman sejawat 2 yang mengamati aktivitas guru.

Berdasarkan observasi minat belajar siswa dalam penerapan model role playing pada siklus I dan siklus II, siswa mulai tertarik ketika guru meminta siswa untuk bermain peran, siswa mulai memperhatikan pembelajaran dengan baik, hal tersebut dilihat ketika guru menjelaskan materi pelajaran siswa tidak bermain dengan temannya. Meskipun ada satu atau dua siswa yang kurang fokus dalam pembelajaran. Selain itu siswa merasa senang dan terlibat aktif dalam pembelajaran berlangsung. Hal ini senada dengan pendapat Putrayasa, Syahruddin dan Margunayasa (2014) bahwa pentingnya minat belajar itu dapat mempengaruhi keantusiasan dan keaktifan siswa dalam proses pembelajaran.

Sedangkan menurut Sabri (Syardiansah, 2016) minat belajar adalah kecenderungan untuk selalu memperhatikan dan mengingat segala sesuatu secara terus menerus yang mana dapat memperbaiki keaktifan siswa sehingga dapat mempengaruhi hasil belajar menjadi baik. Minat terhadap sesuatu dipelajari dan mempengaruhi belajar selanjutnya serta mempengaruhi penerimaan minat-minat baru. Jadi Minat terhadap sesuatu merupakan hasil belajar dan menyokong belajar selanjutnya dalam proses pembelajaran agar mendapatkan hasil yang baik (Slameto (Anggraini, 2013)). Siswa yang memiliki minat maka akan aktif dalam pembelajaran. Pembelajaran diselenggarakan sebaik mungkin dengan tujuan meningkatkan minat belajar siswa.

Hasil minat siswa siklus I pertemuan I menunjukkan bahwa perolehan minat belajar pada siswa kelas V SDN 007 Pulau Lawas mencapai persentase $37,05 \%$ yang mana dalam kriteria sedang. Pada pertemuan kedua skor minat belajar siswa 45,53 \% dalam kategori sedang juga. Pada pelaksanaan tindakan pada siklus I belum menunjukkan adanya pencapaian indikator keberhasilan dalam pembelajaran, pelaksanaan tindakan pada siklus I adanya beberapa hal yang belum maksimal.

Hal tersebut diantaranya yakni ketika siswa diberikan tugas yakni memperhatikan temannya di depan kelas hanya beberapa siswa yang memperhatikannya dan asik melakukan kegiatan sendiri. Peneliti belumlah 
merasa puas karena masih terdapat adanya kendala dalam pelaksanaan penelitian yakni pada pelaksanaan tindakan pada siklus I yang dianggap dapat diatasi dengan refleksi siklus I. Oleh Karena itu peneliti memutuskan untuk melakukan berupa tindakan lagi untuk melakukan tahap refleksi pada siklus I dengan tujuan memperbaiki kendala-kendala yang ada pada pelaksanaan siklus I tersebut.

Pada siklus II, minat belajar siswa kelas V SDN 007 Pulau Lawas pada siklus II pertemuan I yang mana menunjukkan persentase minat belajar siswa sebasar 58,92 \% dengan kategori tinggi dan pada siklus II pertemuan II menunjukkan angka persentase minat belajar siswa sebesar 77,12 \% dalam kategori sangat tinggi. Hal ini menunjukkan bahwa pada siklus II ini indikator keberhasilan peneliti sudah tercapai. Pelaksanaan tindakan pada siklus II, selain terjadi peningkatan pada setiap siklus dalam beberapa pertemuan, hasil refleksi pada siklus I sudah mulai Nampak hasil yang telah direncanakan pada refleksi siklus I.

Model Role Playing ini mampu meningkatkan minat belajar siswa. Akan tetapi lama dalam menumbuhkan secara individu minat belajarnya. Secara klasikal persentasenya naik setiap pertemuan akan tetapi ketuntasan siswa perindividunya tidak seperti yang diharapkan. Berdasarkan hasil tindakan pada siklus II, peneliti memutuskan untuk menghentikan siklus karena indikator keberhasilan sudah tercapai dan kendala-kendala pada refleksi I mulai teratasi pada pelaksanaan siklus II.

\section{Rekapitulasi Minat Belajar Siswa}

Kelas V SDN 007 Pulau Lawas dengan Penerapan Model Role Playing Pada Pra Siklus, Siklus I dan Siklus II

\begin{tabular}{|c|c|c|c|c|c|c|}
\hline \multirow{2}{*}{$\begin{array}{c}\text { N } \\
\mathbf{0}\end{array}$} & \multirow{2}{*}{ Indikator } & \multicolumn{4}{|c|}{ Skor Minat Belajar } \\
\cline { 2 - 7 } & $\begin{array}{c}\text { Pra } \\
\text { Siklus }\end{array}$ & \multicolumn{2}{|c|}{ Siklus I } & \multicolumn{2}{c|}{ Siklus II } \\
\cline { 2 - 7 } & & $\begin{array}{c}\text { Pertemua } \\
\text { n I }\end{array}$ & $\begin{array}{c}\text { Pertemua } \\
\text { n II }\end{array}$ & $\begin{array}{c}\text { Pertemua } \\
\text { n I }\end{array}$ & $\begin{array}{c}\text { Pertemua } \\
\text { n II }\end{array}$ \\
\hline 1 & $\begin{array}{c}\text { Perasaan } \\
\text { Senang }\end{array}$ & 84 & 90 & 105 & 151 & 182 \\
\hline $\begin{array}{c}\text { Kertarikan } \\
\text { siswa }\end{array}$ & 78 & 85 & 98 & 131 & 169 \\
\hline 3 & $\begin{array}{c}\text { Perhatian } \\
\text { Siswa }\end{array}$ & 75 & 82 & 106 & 120 & 173 \\
\hline 4 & $\begin{array}{c}\text { Keterlibata } \\
\text { n siswa }\end{array}$ & 80 & 86 & 99 & 126 & 167 \\
\hline $\begin{array}{c}\text { Jumlah } \\
\text { Keseluruhan }\end{array}$ & 317 & 332 & 408 & 528 & 691 \\
\hline $\begin{array}{c}\text { Persentase } \\
\text { Respon (\%) }\end{array}$ & $\mathbf{3 5 , 2 6}$ & $\mathbf{3 8 , 2 7}$ & $\mathbf{4 5 , 5 5}$ & $\mathbf{5 8 , 9 2}$ & $\mathbf{7 7 , 3 6}$ \\
\hline
\end{tabular}




\begin{tabular}{|c|c|c|c|c|c|c|}
\hline $\begin{array}{c}\text { N } \\
\mathbf{0}\end{array}$ & Indikator & \multicolumn{4}{|c|}{ Skor Minat Belajar } \\
\cline { 3 - 7 } & $\begin{array}{c}\text { Pra } \\
\text { Siklus }\end{array}$ & \multicolumn{2}{|c|}{ Siklus I } & \multicolumn{2}{c|}{ Siklus II } \\
\cline { 3 - 7 } & & $\begin{array}{c}\text { Pertemua } \\
\text { n I }\end{array}$ & $\begin{array}{c}\text { Pertemua } \\
\text { n II }\end{array}$ & $\begin{array}{c}\text { Pertemua } \\
\text { n I }\end{array}$ & $\begin{array}{c}\text { Pertemua } \\
\text { n II }\end{array}$ \\
\hline & & & & & \\
\hline Kriteria & $\begin{array}{c}\text { Sedan } \\
\text { g }\end{array}$ & Sedang & Sedang & Tinggi & $\begin{array}{c}\text { Sangat } \\
\text { Tinggi }\end{array}$ \\
\hline
\end{tabular}

Sumber: Hasil Data Angket Tahun 2020

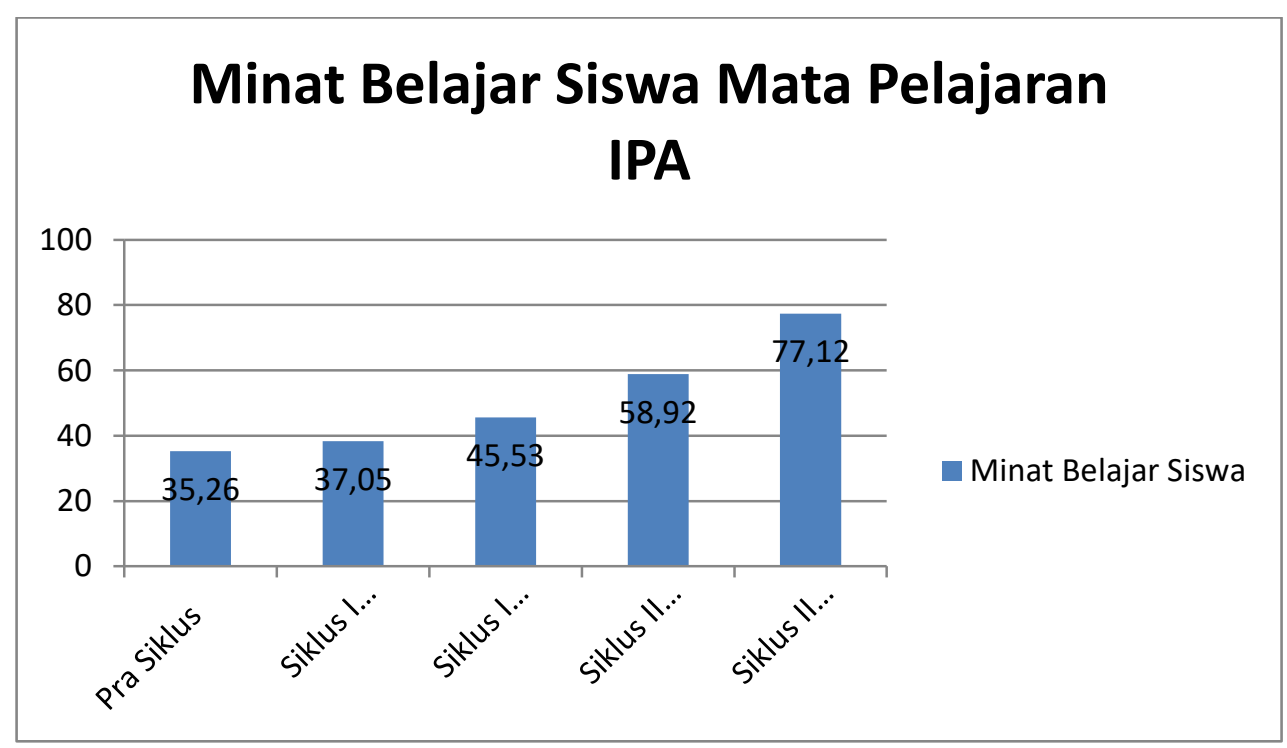

Gambar 4.1

Diagram Minat Belajar Pra Siklus, Siklus I dan Siklus II

Minat Belajar siswa pada Tema Organ Gerak Hewan dan Manusia

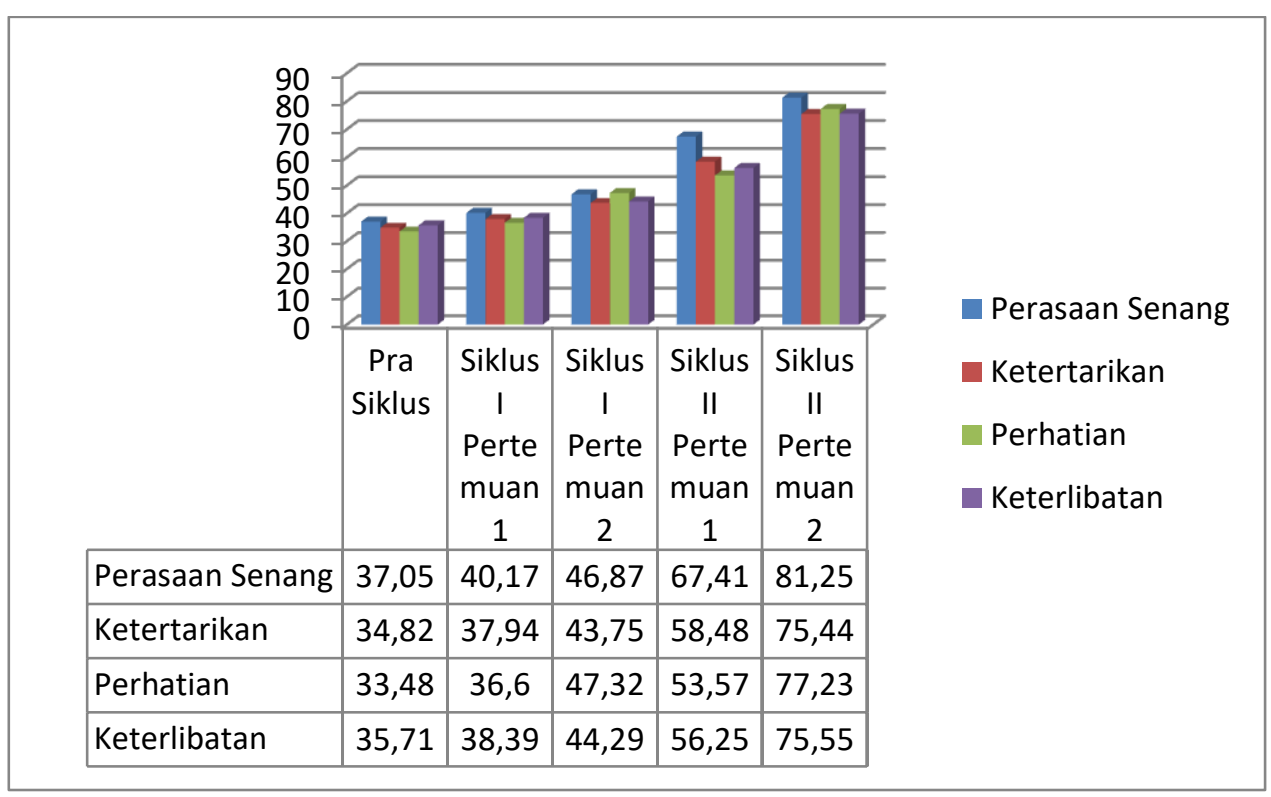

Gambar 4.2

Diagram Indikator Minat Belajar Pra Siklus, Siklus I dan Siklus II 


\section{KESIMPULAN}

Berdasarkan hasil penelitian dan pada pembahasan pada bab sebelumnya yang mana penelitian tindakan kelas yang dilaksanakan di SDN 007 Pulau Lawas, dapat disimpulkan sebagai berikut: 1) Minat belajar pada tema organ gerak hewan dan manusia dengan mengaplikasikan model pembelajaran Role Playing yang dilaksanakan di SDN 007 Pulau Lawas meningkat. Dalam hal ini terlihat setiap pertemuan yang dilaksanakan dalam 2 siklus telah mencapai indikator keberhasilan penelitian yaitu $80 \%$ siswa kelas $\mathrm{V}$ memperoleh nilai minat dalam kategori tinggi. Selain hal demikian juga dapat dilihat terjadinya peningkatan rata-rata minat belajar siswa kelas V SDN 007 Pulau Lawas dari pra siklus ke siklus selanjutnya. Pada Pra siklus atau sebelum diberikan tindakan bahwa minat belajar siswa menunjukkan angka 35,26 \% dengan kategori minat belajar sedang, siklus 1 pertemuan 1 menunjukkan angka 37,05 \% dengan kategori sedang, pada siklus 1 pertemuan 2 menunjukkan angka 45,53\% dengan kategori sedang juga. Pada siklus 2 pertemuan 1 menunjukkan angka 58,92 \% dengan kategori tinggi dan dilanjutkan pada siklus 2 pertemuan 2 menunjukkan angka 77,12 \% dengan kategori sangat tinggi. Minat belajar pada tema organ gerak pada hewan dan manusia sebelum menerapkan model pembelajaran Role Playing pada SDN 007 Pulau Lawas berada pada kategori sedang dengan persentase nilai 35,26 \%. Minat belajar pada tema organ gerak pada hewan dan manusia sesudah menerapkan model pembelajaran Role Playing pada SDN 007 Pulau Lawas berada pada kategori sangat tinggi dengan persentase nilai $77,12 \%$.

\section{DAFTAR PUSTAKA}

Adawiyah. Fahri. (2017). "Hubungan Penggunaan Media Pembelajaran dengan Minat Belajar Siswa pada Pembelajaran Fiqih Kelas IV MI AL Madani Tajur Halang Kab. Bogor". Journal of Elementary Education. Vol. 1, Nomor. 2.

Anggraini. E. (2013). Hubungan Antara Minat Belajar Dan Fasilitas Belajar Siswa Dengan Prestasi Belajar Sosiologi Siswa Kelas Xi Ips Sman 3

Surakarta. Thesis, Surakarta: Teacher Training and Education Faculty. Sebelas Maret University of Surakarta.

Fauziah. A. DKK. (2017). "Hubungan Antara Motivasi Belajar dengan Minat Belajar Siswa Kelas IV SDN Poris Gaga 05 Kota Tanggerang". Jurnal JPSD. VOL. 4, No. 1.

Marleni. L. (2016). "Faktor-Faktor Yang Mempengaruhi Minat Belajar Siswa Kelas Viii Smp Negeri 1 Bangkinang". Journal Cendekia: Jurnal Pendidikan Matematika. Vol. 1, No. 1. 
Maskurin. (2018). "Meningkatkan Motivasi Dan Hasil Belajar Materi Sumber Daya Alam Kegiatan Ekonomi Melalui Penerapan Model Pembelajaran Problem Solving Berbantu Media Gambar Pada Siswa Kelas IV SD 5 Gondosari”. Jurnal Prakarsa Paedagogia. Vol. 1, No. 2.

Nurhasanah. \& Sobandi. (2016). "Minat Belajar Sebagai Determinan Hasil Belajar Siswa”. Jurnal Pendidikan Manajemen Perkantoran. Vol. 1, No. 1.

Nurhasanah. M. (2020). "Role Model Pembelajaran Sebagai Sarana Inovatif Pembelajaran Jarak Jauh Di Masa Pandemi Covid 19". Jurnal Penelitian Pendidikan dan Keagamaan Islam. Vol. 6, No. 1.

Pratiwi. I., DKK. (2018). "Metode Role Playing Untuk Meningkatkan Motivasi Belajar Siswa Kelas Rendah Sdn Kupang Curahdami Bondowoso". Jurnal Unej ac. Id. Prosiding FKIP, Hal. 84-91.

Putrayasa. Syahruddin \& Margunayasa. (2014). 'Pengaruh Model Pembelajaran Discovery Learning dan Minat Belajar Terhadap Hasil Belajar IPA siswa".https://ejournal.undiksha.ac.id/index.php/JJPGSD/article/view/30 87. Vol 2. No 1.

Rahmawati. S. \& Suwarjo. (2016). Peningkatan Keterampilan Berbicara Melalui Metode Bermain Peran Pada Siswa Sd Negeri 58 Kota Bima. Jurnal Fip.

Saraswati, Kristin, dan Anugraheni. (2018). "Peningkatan kemampuan pemecahan masalah matematika menggunakan model means ends analysis (MEA) bagi siswa kelas 5 SD Negeri Sumogawe 02. Jurnal Pendidikan Dasar Perkhasa. V0I 4, (1).

Syardiansah. (2016). "Hubungan Motivasi Belajar dan Minat Belajar terhadap Prestasi Belajar Mahasiswa Mata Kuliah Pengantar Manajemen". Jurnal Manajemen dan Keuangan. Vol. 5, No. 1.

Undang - Undang SISDIKNAS. (2003). Sistem Pendidikan Nasional. Jakarta: Sinar Grafika.

Whusqo, U. (2019). Peningkatan Minat Belajar Menggunakan Model Pembelajaran Team Games Tournament Pada Siswa Sekolah Dasar. Mahasiswa Program Studi Pendidikan Guru Sekolah Fakultas IImu Pendidikan Universitas Pahlawan Tuanku Tambusai Bangkinang. 